\title{
Coexistence of Antibodies to Tick-borne Agents of Babesiosis and Lyme Borreliosis in Patients from Cotia County, State of São Paulo, Brazil
}

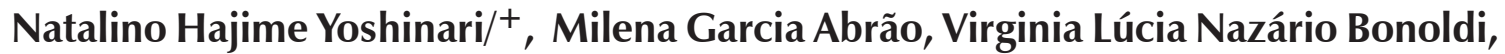 \\ Cleber Oliveira Soares*, Claudio Roberto Madruga* , Alessandra Scofield**, \\ Carlos Luis Massard**, Adivaldo Henrique da Fonseca**
}

\begin{abstract}
Laboratório de Investigação em Reumatologia (LIM-17), Hospital das Clínicas, Faculdade de Medicina, Universidade de São Paulo, Av. Dr. Arnaldo 455, $3^{\circ}$ andar, 01246-903 São Paulo, SP, Brasil *Embrapa Gado de Corte, Campo Grande, MS, Brasil **Universidade Federal Rural do Rio de Janeiro, Seropédica, RJ, Brasil
\end{abstract}

This paper reports a case of coinfection caused by pathogens of Lyme disease and babesiosis in brothers. This was the first case of borreliosis in Brazil, acquired in Cotia County, State of São Paulo, Brazil. Both children had tick bite history, presented erythema migrans, fever, arthralgia, mialgia, and developed positive serology (ELISA and Western-blotting) directed to Borrelia burgdorferi $G 39 / 40$ and Babesia bovis antigens, mainly of IgM class antibodies, suggestive of acute disease. Also, high frequencies of antibodies to B. bovis was observed in a group of 59 Brazilian patients with Lyme borreliosis $(25.4 \%)$, when compared with that obtained in a normal control group $(10.2 \%)$ (chi-square $=5.6 ; p<0.05)$. Interestingly, both children presented the highest titers for IgM antibodies directed to both infective diseases, among all patients with Lyme borreliosis.

Key words: lyme borreliosis - lyme disease - spirochetosis - borreliosis - babesiosis - coinfection - tick-borne disease - Brazil

Babesiosis is a tick-borne disease distributed worldwide, caused by hemoprotozoans of the genus Babesia, which infects wild and domestic animals, promoting economic losses due to mortality, weight loss in cattle population, besides the costs involved in profilatic measures and treatment.

More than 70 species of babesias were described in animals: Babesia bovis, Babesia divergens and Babesia bigemina in cattle; Babesia equi and Babesia caballi in horses; Babesia canis in dogs; Babesia microti in rodents. Recently a new species very similar to B. microti named Babesia $W A-1$ was described in USA (Quick et al. 1993).

The parasite was first discovered by Babes (1888), that reported intra-erytrocytic microorganisms in peripheral blood of cattle suffering of fever and hemoglobinuria. Smith and Kilbourne (1983) identified the tick as transmitter of disease, and this description was the first case of protozoan transmission by arthropods.

The first case of human babesiosis was discovered in Yugoslavia (Skrabalo \& Deanovic 1957) in a 33 years old farmer, splenectomized, who died eight days later with fever, anemia, jaundice and hemoglobinuria, and B. bovis was identified in the blood and cattle. The beggining of knowledge on human babesiosis was dramatic, since three of four cases occurred in splenectomized patients followed by death.

Financial support: Fundação de Amparo à Pesquisa do Estado de São Paulo

${ }^{+}$Corresponding author. Fax: +55-11-3066.7490. E-mail: lyme@lim17.fm.usp.br

Received 7 June 2002

Accepted 10 January 2003
The first case of babesiosis in a healthy person, with intact spleen, was reported in 1969 in a woman from Nantucket Island (Massachusetts, USA)(Wester et al. 1970), hospitalized with fever, headache and abdominal pain. Blood smear analysis revealed numerous ring-like structures suggesting Plasmodium falciparum infection, and the patient was treated with cloroquine. During the course of the disease, diagnosis of babesiosis was established, the treatment with cloroquine was introduced, and longed for two months. Blood from patient was inoculated in splenectomized rodent and monkey, with recovery of the etiological agent B. microti.

The only case reported in Brazil (Alecrim et al. 1983) was described from a patient from Tiuma, State of Pernambuco, who was treated as having malaria, until the discovery of parasites identified as Babesia sp.

Ixodid ticks (Healey et al. 1976, Piesman \& Piesman 1980 ) are responsible vectors for protozoan transmission, and belong to the genus Ixodes (B. microti, B. divergens), Boophilus (B. bovis), Dermacentor (B. equi), Rhipichephalus (B. equi, B. canis).

Humans are infected accidentally by tick bite or blood transfusion. The microorganisms invade the erytrocytes and present binary division, and differently from malaria, the parasite did not have sexual stage.

Human babesiosis or piroplasmosis is a zoonosis associated with protozoa of the family Piroplasmorida including $B$. microti and recently described babesia like piroplasm named Babesia $\mathrm{Wa}-1$ in the USA, and $B$. divergens in Europe. A few cases in humans have been described in China, Egypt, Mexico, South Africa and Taiwan (Gorenflot et al. 1998b).

The North American clinical manifestations of $B$. microti infection present incubation period that varies from one to four weeks, and first clinical manifestations 
include presence of fever, chills, myalgia, fatigue. Symptoms may remain for weeks until the correct diagnosis is done, sometimes with spleen enlargement and anemia. The disease may be asymptomatic or course as prolonged severe illness (Telford III et al. 1993). The clinical spectrum associated with $B$. Wa-l ranges from asymptomatic infection or influenza-like illness to fulminant fatal disease (Persing et al. 1995).

Between 1982 and 1993, 139 patients were hospitalized with babesiosis in the State of New York (White et al. 1998), nine patients died (6.5\%), and the most common symptoms were fever, myalgia, headache, fatigue, malaise, weakness, hemolytic anemia, jaundice, hemoglobinuria. Among these patients, $12 \%$ had had previous history of Lyme disease, $12 \%$ had undergone splenectomy and $2 \%$ blood transfusion.

Osorno et al. (1976) performed an epidemiological survey at a risk area analysing 101 blood samples, and found antibodies to Babesia sp. in 38\%, demonstrating that infection may be latent or asymptomatic.

The European presentation of infection in most of cases $(76 \%)$ is caused by $B$. divergens, often it is a dramatic medical emergency, with letality close to $50 \%$, and it is clinically characterized by acute onset with appearance of high fever, chills, vomit, nausea, and important anemia, often followed by jaundice, hemolysis, hemoglobinuria, renal failure, pulmonary edema and death. In general, human cases were reported in splenectomized persons (Loutan 1995). Babesiosis must also be considered as differential diagnosis of febrile process in HIV positive patients in endemic areas (Falagas \& Klempner 1996).

First case of human babesiosis in Poland (Humiczewska \& Kuzna-Grygiel 1997) was diagnosed as imported from Brazil, and it was based on recovery of parasite after intraperitoneal inoculation of patient's blood in hamster, when characteristic forms of babesia were identified.

Diagnosis of human babesiosis includes history of visiting risk areas and development of clinical manifestations as fever, hemolitic anemia with normal leucogram, slight elevation of transaminases and alkaline fosfatase enzymes (Telford III et al. 1993).

Laboratorial confirmation includes analysis of peripheral blood smear stained by Giemsa or Wright methods, searching for protozoan of 1 to $3 \mu \mathrm{m}$ diameter, located at erythrocyte citoplasm, morphologically very similar with Plasmodium sp. parasites. Intravenous or intraperitoneal blood inoculation in hamster, gerbil or mice may be helpful to identify microorganisms, when parasitemia occurs after two to four weeks. Serologic assays (IF, ELISA) may reveal cross reactivity with malaria infection (Telford III et al. 1993). PCR is indicated when other methods had failured (Persing \& Conrad 1995, Krause et al. 1998).

Treatment of human babesiosis is done using quinine $600 \mathrm{mg} 3$ times/day given orally, asssociated to clindamycin $600 \mathrm{mg} 3$ times/day intravenously during 10 days (Gorenflot et al. 1998a).

Lyme borreliosis has been diagnosed since 1992 in Brazil (Yoshinari et al. 1992a,b, 1993, 1997, Barros et al. 1993, Pirana et al. 1996, 1999, 2000), and nowadays it is considered an important differential diagnosis with interest to physicians of different specialities, because it pro- motes systemic complications like cutaneous, rheumatic, neurologic and cardiac symptoms. The etiological agent is different in Brazil, and not isolated yet (Abel et al. 2000). The probable ticks transmitters of disease belong to the genus Ixodes and Amblyomma, the first implicated for keeping infection among wild animals, and the latter for promoting human disease (Barros-Battesti et al. 1995, 2000). Due to etiological, clinical and laboratorial differences when compared with American and European presentations, the infection has been named Lyme disease like illness in Brazil (Yoshinari et al 1999, 2000).

The aim of the present paper is to report the presence of simultaneous infections caused by etiological agents of Lyme disease like illness and babesiosis in two brothers who acquired disease in Cotia county, State of São Paulo, in 1992. Interestingly, they were the first cases of borreliosis with cutaneous and systemic symptons, with positive serology for B. burgdorferi G39/40 of American origin. Clinical suspicion was done by Dr Marcelo Mendonça when the boys were hospitalized at Instituto de Infectologia Emílio Ribas, and the laboratorial confirmation performed at Laboratório de Investigação em Reumatologia, Hospital das Clínicas, Faculdade de Medicina, Universidade de São Paulo (LIM-17). Serologic test for B. bovis was done only in 2000 at LIM-17, employing frozen sera kept at $-70^{\circ} \mathrm{C}$ during eight years.

\section{PATIENTS AND METHODS}

Case 1 - EMDA, 10 years, male, white, resident in São Paulo city. The boy started with fever 19 days before hospitalization, followed by cutaneous lesions on elbows and knees, with latter dissemination on trunk and members, associated with headache, anorexia, myalgia, nausea, arthralgia of wrists. The skin lesions were multiple, expansive, and of different size, very suggestive of erythema migrans (EM).

The boy had visited an ownership of 125 hectares, named Transurb, located in Cotia, which is a region covered with Atlantic Forest, 20 days before the beginning of symptons, and presented important epidemiological data like the history of contact with dog that died few days latter, and many episodes of tick bite, because parents were building a house in this ownership. Many species of wild animals were present in this geographic region.

The hemogram was normal, serum protein electrophoresis showed elevated alfa-2, beta and gamaglobulins with normal albumin. Sera biochemical results as transaminases, alkaline phosphatase, urea, creatinine, amylase and urinalysis were all normal. Antinuclear antibodies (ANA), rheumatoid factor, serology for spotted fever, leptospirosis, syphilis, mononucleosis, citomegalovirus, toxoplasmosis, mucoproteins, C-reactive proteins were negative.

Serologic tests (ELISA and Western blotting-WB) for Lyme disease were performed using American whole sonicated antigen of B. burgdorferi G39/40 strain. The first serum sample collected soon after hospitalization showed positive ELISA with IgM titer of $1 / 400$, confirmed by WB that revealed several bands for IgM antibodies (Fig.1).

After laboratorial confirmation of Lyme borreliosis, treatment was introduced with $100 \mathrm{mg}$ of doxicicline, twice a day, given for one month. Fever persisted for 14 days 
after antibiotic introduction, and fatigue lastened for one month after the end of treatment.

Second blood sample collected 14 days after the beginning of treatment showed IgM titer of 1/100 (ELISA) (Fig. 1), and the last test done three months latter revealed negative ELISA assay. However, few bands for IgG antibodies appeared at WB, revealing changes of immunoblotting pattern during the disease evolution.

Case 2 - BMDA, 12 years old, male, white, resident in São Paulo, brother of EMDA, and same epidemiological history.

The boy started with fever 30 days after tick bite history, appearance of skin lesions on members, and diarrhea 5 days after the beginning of fever. Physical examination showed cutaneous lesions suggesttive of EM on elbows, arms and thighs.

Culture of feces was positive for Salmonella sp. Hemogram was normal, protein electrophoresis showed alfa 2 and gamaglobulin elevations, and others tests done to identify etiological agent were negative, except for Lyme disease serology. All the biochemical analysis done in the blood were normal.

ELISA and WB for B. burgdorferi were positive for IgM class antibodies in the beginning and 14 days after doxicicline introduction (Fig. 1). Serology repeated three months latter was negative. The patient recovered completely after one month of antibiotic therapy.

\section{Serology for B. bovis}

Enzyme-linked immunosorbent assay (ELISA) - It was standardized at LIM-17 of Hospital das Clínicas, Universidade de São Paulo, employing B. bovis antigens offered by Dr CR Madruga from Embrapa Gado de Corte, Campo Grande, MS, Brazil. Briefly, according to Kessler et al. (1987), methodology, infected erythrocytes with a parasitemia of $23 \%$ obtained from splenectomized calf, experimentally-inoculated with an isolate of $B$. bovis, were centrifuged three times with PBS pH 7.2, and stored at $-72^{\circ} \mathrm{C}$. The lised erythrocytes were centrifuged three times at $10,000 \mathrm{~g}$ during $30 \mathrm{~min}$ at $4^{\circ} \mathrm{C}$ and washed with $\mathrm{PBS} \mathrm{pH}$ 7.2. After the last centrifugation, the intermediate layer was collected and lysed with a buffer containing $100 \mathrm{mM}$ Tris, 10 mM EDTA, 2\% NP40, 0.2 mM N-alfa-ptosyl-Llysil chloromethyl ketone (TLCK) and $2 \mathrm{mM}$ phenylmethyl sulphonylfluoride (PMSF), and ultrasonic disruption (100 W) for $10 \mathrm{~min}$ with interval of $2 \mathrm{~min}$. The soluble material obtained after centrifugation for $60 \mathrm{~min}$ at $14,000 \mathrm{~g}$ and $4^{\circ} \mathrm{C}$ was used as antigen. Protein concentration was established by Folin method.

The ELISA was done by standart method (Voller et al. 1989) with modifications. Briefly, the microtitrations plate (Immulon) were coated with $200 \mu \mathrm{l}$ of a $7.5 \mathrm{mg} / \mathrm{ml}$ solution of $B$. bovis antigens diluted in $0.05 \mathrm{M}$ sodium carbonate pH 9.6 and incubated overnight at $4{ }^{\circ} \mathrm{C}$. The plates were washed three times with PBS containing $0.05 \%$ Tween 20 and blocked with $1 \%$ rabbit serum diluted in PBS TW-20 $0.05 \% \mathrm{pH} 7.4$. The washing procedure was repeated and test samples were diluted at $1 / 100$ for IgM and $1 / 400$ for IgG antibodies with blocking solution. Positive bovine serum diluted using serial two ratio dilution and sera of eight normal human beings were employed as negative control. After incubation at room temperature, the washing procedure was repeated and the conjugate diluted at 1/2000 in PBS was added (Sigma-goat anti human IgG and IgM alkaline phosphatase conjugated; except for the bovine positive control diluted serially that was incubated with rabbit anti bovine IgG alkaline phosphatase conjugated). Finally, it was added the substrate p-nitrophenyl sodium phosphate (Sigma) diluted at $1 \mathrm{mg} / \mathrm{ml}$ in glicine buffer $\mathrm{pH}$ 10.5. The plates were read at $405 \mathrm{~nm}$ in

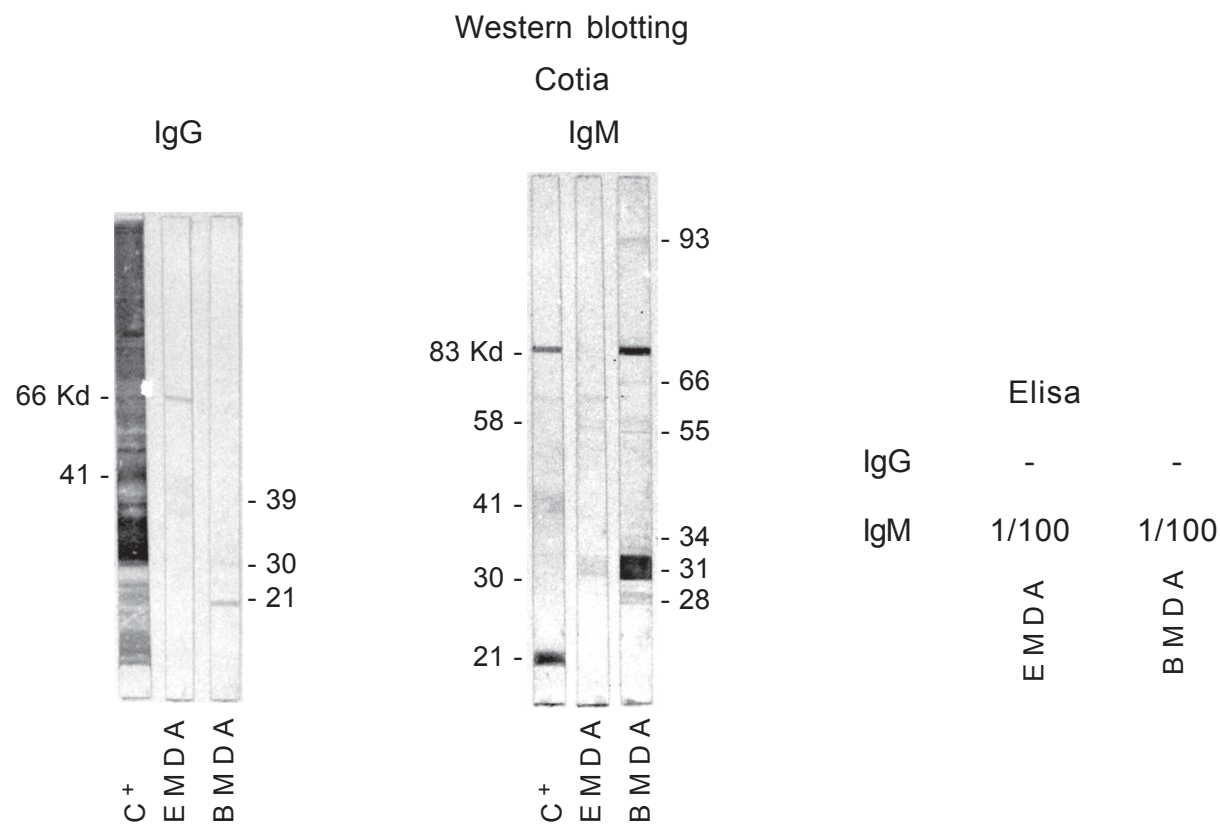

Fig.1: sequential serological analysis (Elisa and western blotting) for Borrelia burgdorferi in the sera of brothers with Lyme borreliosis (patients EMDA and BMDA). 
microplate reader (Titertek Multiscan MCC/340, Flow Laboratories), and the assay stopped when the first dilution of the positive control serum reached the optical density value near 1.0 .

Cut off value was obtained by considering the mean optical density plus three standart deviations of the eight control sera. Optical densities higher than cut off values were positive, and the titers were estimated by regression curve.

To date, in the laboratory (LIM-17), it is possible to substitute bovine positive control for human sera, because some sera obtained from patients with Lyme borreliosis, including sera of patients EMDA and BMDA, presented high titers of IgM and IgG antibodies to $B$. bovis.

Western blotting (WB) - Electrophoresis and immunoblotting were done as previously described with modifications (Grodzick \& Steere 1988, Joppert et al. 2001). Briefly, $600 \mu \mathrm{g}$ of B. bovis antigens reduced with SDS, were electrophorezed (Mini-Protean II System, Bio Rad) on a $10 \%$ acrylamide gel. After running, gel proteins were transferred to nitrocellulose paper over night (Mini-Trans Blot System, Bio Rad), and the paper cut in vertical strips, which were washed in distilled water. One strip containing $B$. bovis antigens and another with molecular weight markers were stained with a solution 1:1 of colloidal gold (Bio Rad). The others strips were blocked with $1 \%$ rabbit serum diluted in TBS Tween $20,0.1 \% \mathrm{pH} 7.4$ for $1 \mathrm{~h}$ at room temperature, and then washed five times with TBS Tw-20, $0.1 \%$. The test samples including positive and negative controls, were diluted 1:100 in blocking solution and added to incubate with strips for $1 \mathrm{~h}$ at room temperature. After washing, the strips were incubated with goat anti human $\mathrm{IgG}$ and IgM alkaline phosphatase conjugated (Sigma Chemical) diluted at 1:6000 for IgG and 1:3000 for IgM antibodies detection in blocking solution. Washing process was repeated and substrate consisting of NBT/ BCIP diluted in carbonate buffer $\mathrm{pH} 9.8$ was added. The reaction was stopped with distilled water when positive control developed color.

Note: bovine serum rich in IgG antibodies for B.bovis was used in the beginning until the discovery of a positive human control. Adequate conjugate was used, acccording to each standardized assay.

\section{RESULTS}

Sera of the patients presented high titers of IgM and $\mathrm{IgG}$ antibodies to $B$. bovis proteins, when compared with negative controls, and also reached optical density (OD) at same time of that observed with positive bovine serum at ELISA assay for IgG antibodies detection.

During the standardization stage of ELISA assay for babesiosis in humans, it was done a preliminary assay with 36 sera samples obtained from normal donnors, aiming to calculate the mean value $(\bar{x})$ and standard deviation $(\sigma)$ of the assays for detection IgG and IgM antibodies to $B$. bovis. ELISA for IgG antibodies in this normal group presented $\overline{\mathrm{x}}=0.022$ and $\sigma=0.016$, and the cut off (mean value plus three standart deviations) obtained was equal to 0.070 . ELISA for IgM antibodies revealed $\overline{\mathrm{x}}=$ 0.077 and $\sigma=0.086$, with cut off of 0.335 . Then, it was possible to choose eight of these 36 sera samples which could represent the normal group.

After that, ELISA was performed in another group of 49 normal individuals, using the eight previously selected sera as control group, permitting to know the frequency of sero-positivity to babesiosis in a normal population. Eight of 46 sera (8.2\%) were positive for IgG antibodies to B. bovis, and only two in $49(2.04 \%)$ were positive for IgM antibodies. The study demonstrated that the frequency of antibodies (IgG or IgM) against babesiosis in a control group was of $10.2 \%$.

ELISA tests for babesiosis were done in 59 patients with Brazilian Lyme borreliosislis. It was found positivity in $10 / 49$ patients ( $16.9 \%$ ) for $\mathrm{IgG}$ antibodies and in $9 / 45$ $(15.25 \%)$ for IgM antibodies against $B$. bovis. Fifteen of 59 patients $(25.42 \%)$ presented IgG or IgM antibodies to babesia antigens. Statistical analysis (chi-square test) demonstrated that patients with Lyme borreliosis presented higher frequency of isolated IgM (chi-square $=$ 5.6; $\mathrm{p}<0.05$ ), and $\operatorname{IgM}$ or $\operatorname{IgG}$ antibodies (chi-square $=$ $4.11 ; \mathrm{p}<0.05$ ) when compared to control group. Surprisingly, the highest titers of $\operatorname{IgG}$ and $\operatorname{IgM}$ antibodies to $B$. bovis were observed with the sera of patients EMDA and BMDA, which were the first cases of Lyme borreliosis discovered in Brasil.

These results were confirmed by WB. Fig. 2 compares presence of $\operatorname{IgG}$ antibodies in the positive bovine serum with those found in both patients with Lyme borreliosis (EMDA and BMDA). Fig. 3 shows a sequential WB of patients, when the first sample was collected whith 15 days of hospitalization (I), and the second after three months of follow up (II). The latter WB (II) revealed that number and intensity of $\mathrm{IgM}$ and $\operatorname{IgG}$ bands directed to babesia, increased during the clinical recovery of both children. IgM antibodies recognized $B$. bovis antigens of $24,50,66$ and $97 \mathrm{KDa}$, while IgG reacted with proteins of $24,45,66,85$ and $106 \mathrm{KDa}$

In an attempt to discard hypothesis of cross-reactivity between antibodies to B. burgdorferi and B. bovis, diluted sera of patients were previously incubated "over night" with spirochetal antigens fixed in polystirene EIA/ RIA plate. The supernatant was used for repeat ELISA

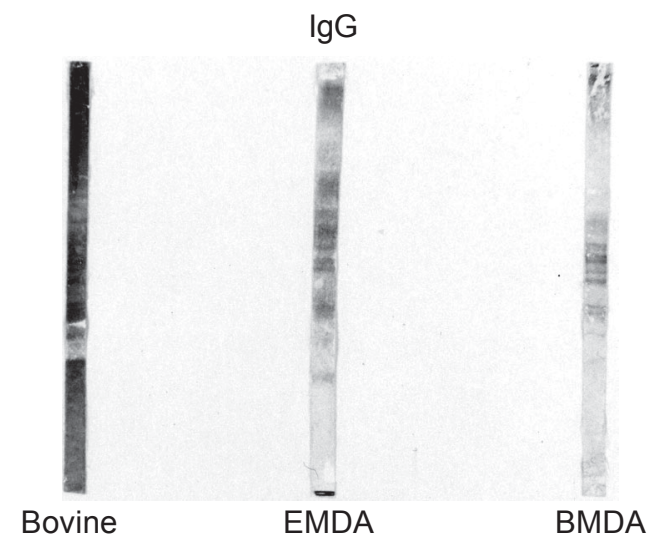

Fig. 2: western blotting (IgG) against Babesia bovis antigens using positive bovine control and sera of brothers with Lyme borreliosis (patients EMDA and BMDA). 

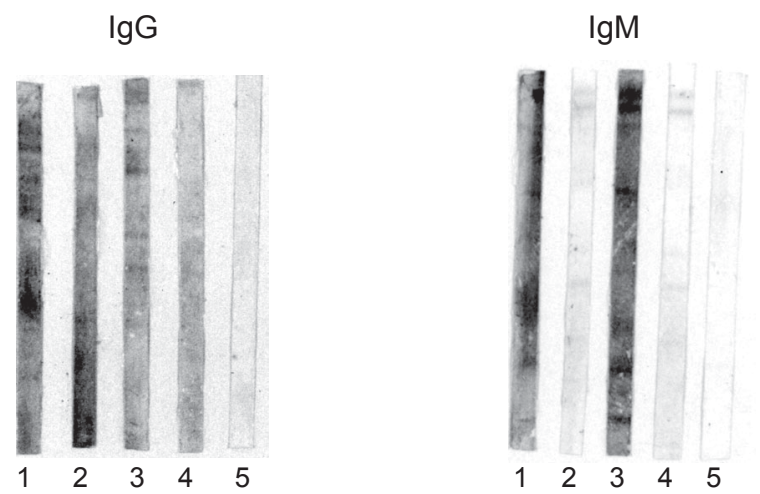

\author{
1 - BMDA (I) \\ $2-\operatorname{EMDA}(\mathrm{I})$ \\ 3 - BMDA (II) \\ 4 - EMDA (II) \\ 5 - Negative control
}

Fig. 3: sequential western blotting (IgM and $\operatorname{IgG}$ ) against Babesia bovis in brothers with Lyme borreliosis (patients EMDA and BMDA); (I) serology done at hospitalization date; (II) serology done three months latter.

and WB against babesia antigens, wich revealed similar results with that obtained with not adsorved sera (data not shown). Otherwise, repeated serology (ELISA) using these adsorved sera against $B$. burgdorferi showed decreased reactivity

The demonstration of parasites in peripheral blood of patients was impossible, because only frozen sera kept frozen at $-80^{\circ} \mathrm{C}$ since 1992 , were available for serological tests.

\section{DISCUSSION}

Lyme borreliosis is an emerging zoonosis in Brazil, and identification of new clinical suspected patients is growing fast, because physicians are concerned about the epidemiological and clinical aspects of the disease.

The present manuscript demonstrates existence of coinfection with etiological agents of Lyme borreliosis and babesiosis in Brazilian population, which is an original and important conclusion. Surprisingly, this discovery was more evident studying the sera of brothers, who were the first cases of Lyme borreliosis in our country. This coinfection was confirmed when ELISA and WB were performed in 59 patients with Brazilian Lyme borreliosis, when it was proved that the frequencies of antibodies directed to $B$. bovis were significantly higher in this group with borreliosis, when compared with normal population.

We have not identified babesias in the peripheral blood smears stainned by Giemsa, neither hematologic or serum biochemical abnormalities in patients with Lyme borreliosis. For these reasons, we believe that babesia infection, in most of the cases is probably asymptomatic. Otherwise, the interaction between infective parasite and human must be different in immunossupressed individuals.

Many publications report coinfection in humans and animals caused by different tick-borne pathogens as borrelia, rickettisia, babesia, ehrlichia, and virus (Steere 2001). Physicians must think about coinfections, when the clinical picture is different from that seen with isolate infection. In such cases, is required additional laboratorial analysis, and eventual association of drugs to control the coinfection.
Patient EMDA presented prolonged fatigue that lastened one month after the end of antibiotic treatment. This kind of feature eventually is part of Lyme borreliosis, but is also a common complaint described in association with babesiosis (Krause et al. 1996)

Patients coinfected with borrelias and babesias can experience a lot of complains for a longer period of time. The main clinical manifestations found in coinfected individuals included fatigue, headache, sweats, chills, anorexia, emotional lability, conjuntivitis and splenomegaly. Serological survey done in 1156 subjects from Rhode Islands (USA) showed that 97 (8.4\%) were sero reactive against Lyme disease spirochete antigens, of whom 14 (14\%) also reacted against babesia antigens. In this community, in a group of 240 patients diagnosed with Lyme disease, $26(11 \%)$ were coinfected with babesiosis, and $50 \%$ of these patients were symptomatic for three months or longer, concluding that patients whith both infections experienced additional manifestations and persistence of illness (Krause et al. 1996).

Hilton et al. (1999) studied sero prevalence and seroconversion for tick borne diseases in a high-risk group in Long Island, NY, searching for antibodies to Rocky Mountain spotted fever, Lyme disease, ehrlichiosis and babesiosis. In the population of 671 individuals, 88 $(13.2 \%)$ presented antibodies to one or more tick borne agents, including 34 (5\%) with antibodies to $B$. burgdorferi. Seven participants seroconverted during one year follow up, five of whom were symptomatic for Lyme disease. Antibodies to spotted fever group rickettisiae were observed in 28 participants $(4.1 \%)$, six had seroconvertion during the study, and none had symptons of the disease. Twenty four individuals (3.5\%) had serologic evidence of exposure to Ehrlichia sp.; five seroconverted $(0.7 \%)$, and three subjects were asymptomatic. Antibodies to $B$. microti were seen in seven participants (1\%) including one asymptomatic seroconversion during the period of the study. The authors concluded that in a highrisk population, there was evidence of seroconvertion, however many infections were asymptomatic, and coinfection were rare. 
Magnarelli et al. (1995), studied coexistence of antibodies to tick-borne pathogens of babesiosis, ehrlichiosis, and Lyme disease in human sera obtained in Connecticut and Minesota, USA. There was serologic evidence of exposure to multiple infectious agents in 15 of $227(6.6 \%)$ samples. Of these, 10 samples were from patients who had had previous Lyme disease. The authors did not find cross-reactivity among the antisera and antigens tested for the four tick-borne pathogens, and recommended to search for coinfection when clinical picture was unclear.

Coinfection with agents of human granulocitic ehrlichiosis, Lyme disease and babesiosis was observed in wild white-footed mice (Peromyscus leucopus) in Connecticut (Stafford et al. 1999). Twenty three of 48 (47.9\%) captured animals, presented antibodies to Ehrlichia sp. strains determined by indirect immunofluorescense method, and the majority (83.3\%) of mice had antibodies to $B$. burgdorferi identified by ELISA. Moreover, 20 of 26 $(76.9 \%)$ animals presented antibodies to B. microti detected by indirect IF method.

The present paper demonstrates the existence of coinfection of Lyme borreliosis and babesiosis pathogens in Brazil, identified by serological methods. Also, it was not observed serological cross-reactivity between these agents. Otherwise, it is possible to assume that human babesiosis is misdiagnosed and perhaps confused with malaria, which is a very commom disease in our country. Serological discernment is not easy, because there are reports of cross-reactivity among protozoal infections of the phylum Apicomplexa, including organisms of the genera Plasmodium, Babesia, Toxoplasma and Cryptosporidium, which are closely related organisms (Kemper 1997).

Babesia and plasmodium infections present similar clinical manifestations, both having symptoms like headache, fever, chills, disseminated intravascular coagulation, anemia with diserythropoiesis, hipotension, respiratory distress, and renal insufficiency (Clark \& Jacobson 1998). Due to these reasons, it is reasonable to accept that is difficult to establish differential diagnosis between malaria and babesia infections at risk areas where both diseases are endemic.

We have done serology for $B$. bovis in other groups of diseases with the aim to discharge possibility of serological cross-reactivity with others clinical entities. Abrão (2001) performed ELISA test in the sera of 30 patients with diffuse connective disease (10 systemic lupus erythematosus, 10 scleroderma and 10 rheumatoid arthritis), 26 with syphilis, 102 with facial palsy, 28 with septicemia caused by different bacterias, 38 with rheumatic fever, and the final conclusion was that only the group of patients with Lyme borreliosis presented high frequencies of antibodies against babesia antigens, when compared with control group.

Ishikawa et al. (1997), standardized serology for $B$. burgdorferi in cattle in Brazil, performing ELISA assay to detect IgG class antibodies in two bovines, one of them immunized with heat-inactivated suspension of borrelias, and the other inoculated with sterile PBS. The study permitted to analyse the sequential synthesis of antibodies in sensitized and testimony animals. Ishikawa (2000), showed that when the mentioned bovines, were submit- ted to different challenges, like vaccinations (carbuncle, brucelosis and leptospirosis), natural infections ( $B$. bigemina, B.bovis, Anaplasma marginale) and spontaneous infestations by Boophilus microplus, presented in same instances, modifications of B. burgdorferi IgG antibodies titer. The main conclusions related to our research were that natural infections due to mentioned protozoans, confirmed by demonstration of parasites in the blood and serologic diagnosisy, did not modify the antibody production against $B$. burgdorferi in cattle, while vaccination against leptospirosis and natural ticks infestation changed antibody synthesis. These data confirm the absence of humoral cross reactivity between borreliosis and babesiosis.

Some questions on Lyme borreliosis remain unsolved. Previous epidemiological studies performed at risk areas for Lyme borreliosis in Cotia, State of São Paulo (BarrrosBattesti et al. 1995, 2000), and in Campo Grande, State of Mato Grosso do Sul (Costa et al. 2002) demonstrated the presence of Ixodid ticks of genus Amblyomma and Ixodes (not found in Campo Grande), considered as potential vectors of Lyme borreliosis in Brazil. Otherwise, babesiosis in our country is a tick-borne disease transmitted by other species of ticks (B. microplus, Rhipicephalus sanguineus, Dermacentor sp.), which becomes difficult to understand how coinfection happened. It is possible to admit the existence of another species of vector, or presence of a different strain of babesia present among wild or domestic animals, with particular biological and epidemiological features, undiscovered yet.

Also, in the present study we employed B. bovis antigens to do ELISA and WB assays, but it is possible to admit existence of cross-reactivity between different species of babesias. Particularly important, was the epidemiological history that the boys had presented contact with dog that died a few days latter. In the ownership, others domestic animals like bovines and horses were identified.

The research on Lyme borreliosis in Brazil is a challenge, since etiologic agent(s), vector transmitter(s) and laboratorial diagnosis are quite different from that observed in USA or Europe. Etiological agent does not grow in BSK medium, and PCR done with use of known primers, is not capable to identify borrelias in ticks, humans, and reservoirs. The existence of disease is based on identification of patients with classical clinical features of disease, including the finding of characteristc erythema migrans. Borrelia-like microorganisms has been demonstrated by dark field microscope in blood and cerebrospinal fluid of patients. Due to these particularities, the disease has been named Lyme disease like illness in our country.

Despite many questions not completely understood concerning Lyme borreliosis in Brazil, identification of new cases by physicians of different specialities, is growing fast, often with discovery of unusual clinical aspects of this emerging zoonosis of great medical interest. The good terapeutic response and follow up, mainly of early diagnosed patients, are strong stimulus to keep looking for solutions of unsolved questions. Description of coexistence of borreliosis with another tick borne-disease is 
an important medical report, since physicians may be prepared to diagnose Lyme borreliosis with uncommon clinical evolution, making possible to introduce therapeutic changes, and making easy the patient recovery.

\section{REFERENCE}

Abel IS, Marzagão G, Yoshinari NH, Schumaker TTS 2000. Borrelia-like spirochetes recovered from ticks and small mammals collected in the Atlantic Forest Reserve, Cotia County, State of São Paulo, Brazil. Mem Inst Oswaldo Cruz 95: 621-624.

Abrão MG 2001. Sorologia para Babesia bovis em Pacientes com Doença de Lyme-símile, Sifilis, Septicemis, Doenças Autoimunes, e Contactantes de Areas de Risco, Monograph presented at Faculdade de Medicina, Universidade de São Paulo, to obtain certificate of especialization at "Aprimoramento de Pesquisa em Reumatologia”.

Alecrim I, Pinto B, Avila T, Costa R, Pessoa I 1983. Registro do primeiro caso de infecção humana por Babesia spp. no Brasil. Rev Patol Trop 12: 11-29.

Babes V 1888. Sur l'hemoglobinurie bacterienne du boef. Acad Sci 107: 692-694.

Barros PJL, Levy LH, Monteiro FGV, Yoshinari NH 1993. Doença de Lyme. Acometimento cutâneo e tratamento das fases iniciais. Rev Ass Med Bras 39:170-172.

Barros-Battesti DM, Arzua M, Yoshinari NH, Schumaker TTS 1995. Ectoparasitas (Acari e Siphonaptera) de marsupiais capturados em área de risco para a doença de Lyme, município de Itapevi, SP. Rev Patol Trop 23(Supl.): 215.

Barros-Battesti DM, Yoshinari NH, Bonoldi VLN, Gomes AC 2000. Parasitism by Ixodes didelphidis and I. loricatus (Acari:Ixodidae) on small wild mammals from na Atlantic Forest in the State of São Paulo, Brazil. J Med Entomol 37: 820-827.

Clark IA, Jacobson LS 1998. Do babesiosis and malaria share a common disease process? Ann Trop Med Parasitol 92: 483481.

Costa IP, Bonoldi VLN, Yoshinari NH 2002. Search for Borrelia sp. in ticks collected from potencial reservoirs in an urban forest reservoir in the State of Mato Grosso do Sul, Brazil: a short report. Mem Inst Oswaldo Cruz 97: 631635.

Falagas ME, Klempner MS 1996. Babesiosis in patient with AIDS: a chronic infection presenting as fever of unknown origin. Clin Infect Dis 22: 809-812.

Gorenflot A, Bazin C, Ambroise-Thomas P 1998a. Babésioses humaines; traitement des formes graves. Presse Medicale 16: 1099 .

Gorenflot A, Moubri K, Precigout E, Carcy B, Schetters TP 1998b. Human babesiosis. Ann Trop Med Parasitol 92: 489501.

Grodzick RL, Steere AC 1988. Comparision of immunoblotting and indirect enzyme-linked immunosorbent assay using different antigen preparations for diagnosing early Lyme disease. J Infect Dis 157: 790-797.

Healey GR, Spielman A, Gleason M 1976. Human babesiosis: reservoir of infection on Nantucket Island. Science 192: 479-480.

Hilton E, DeVoti J, Benach JL, Halluska ML, White DJ, Paxton H, Dumler JS 1999. Seroprevalence and seroconversion for tick-borne diseases in a high-risk population in the Northeast United States. Am J Med 106: 404-409.

Humiczewska M, Kuzna-Grygiel W 1997. A case of imported human babesiosi. Poland Wiad Parazytol 43: 227-229.

Ishikawa MM 2000. Pesquisa de Anticorpos Anti Borrelia burgdorferi em Condições Experimentais e de Infecções
Naturais em Bovinos, $\mathrm{PhD}$ thesis, Universidade Federal do Rio de Janeiro, Rio de Janeiro, 79 pp.

Ishikawa MM, Fonseca AH, Soares CO, Massard CL, Yoshinari NH 1997. Padronização de ensaio imunoenzimático ELISA indireto para pesquisa de anticorpos da classe IgG contra Borrelia burgdorferi em bovinos. Rev Bras Med Vet 19: 166-168.

Joppert AM, Kuribayashi M, Yoshinari NH 2001. Borrelia burgdorferi antibodies in dogs from Cotia County, São Paulo State, Brazil. Rev Inst Med Trop S Paulo 43: 251-255.

Kemper CA 1997. Pulmonary disease in selected protozoal infections. Sem Resp Infect 12: 113-121.

Kessler RH, Madruga CR, Jesus EF, Semprebom DV 1987. Isolamento de cepas puras de Babesia bovis e Anaplasma marginaale em áreas enzoótica. Pesq Agropec Bras 22: 747752.

Krauser PJ, Spielman A, Telford SR III, Sikand VK, Diane C, Sikand VJ 1998. Persistent parasitemia after acute babesiosis. New Engl J Med 339: 160-165.

Krauser PJ, Telford SR III, Spielman A, Sikand V, Ryan R, Christianson D, Burke G, Brassard P, Pollack R, Peck J, Persing DH 1996. Concurrent Lyme disease and babesiosis. Evidence for increased severity and duration of illness. JAMA 275: 1657-1660.

Loutan L 1995. Babesiosis, a little-known zoonosis. Schweiz Med Wochenschr 125: 886-889.

Magnarelli LA, Dumler JS, Anderson JF, Johnson RC, Fikrig E 1995. Coexistence of antibodies to tick-borne pathogens of babesiosis, ehrlichiosis, and Lyme borreliosis in human sera. J Clin Microbiol 33: 3054-3057.

Osorno BM, Veja C, Ristic M, Robles C, Barra S 1976. Isolation of Babesia spp. from asymptomatic human beings. Vet Parasitol 2: 111-120.

Persing DH, Conrad PA 1995. Babesiosis: new insights from phylogenetic analysis. Inf Agents Dis 4: 182-195.

Persing DH, Herwaldt BC, Glaser C, Lane RS, Thomford JW, Mathiesen D, Krauser PJ, Phillip DF, Conrad PA 1995. Infection with a babesia-like organism in northern California. New Engl J Med 332: 298-303.

Piesman J, Piesman A 1980. Human babesiosis on Nantucket Island. Prevalence of Babesia microti in tick. J Trop Med Hyg 29: 742-746.

Pirana S, Bento RF, Bogar P, Silveira JAM, Yoshinari NH 1996. Paralisia facial e surdez súbita bilateral na doença de Lyme. Rev Bras Otorrinol 62: 500-502.

Quick RE, Herwaldt BL, Thomfor JW, Garnett ME, Eberhard ML 1993. Babesiosis in Washington state: a new species of babesia? Ann Intern Med 119: 284-290.

Skrabalo Z, Deanovic Z 1957. Piroplasmosis in man. Report on a case. Med Geo Trop 9: 11-16.

Smith T, Kilbourne FL 1983. Investigation into the nature, causation and prevention of Texas or South Cattle fever. USDA Bur Animal Industry Bull 1: 1.

Stafford KC III, Massung RF, Magnarelli LA, Ijdo JW, Anderson JF 1999. Infections with agents of human granulocytic ehrlichiosis, Lyme disease, and babesiosis in wild whitefooted mice (Peromyscus leucopus) in Connecticut. J Clin Microbiol 37: 2887-2892.

Steere AC 2001. Lyme disease. New Engl J Med 345: 115-125.

Telford III SR, Gorenflot A, Brasseur P, Spielman A 1993. Babesial infections in humans and wildlife. In JP Kreier Parasitic Protozoa, 2nd ed., Academic Press, San Diego, Vol. 5, p. 1-47.

Voller A, Bidwell DE, Bartlett A 1989. Enzyme immunoassays in diagnostic medicine: theory and practice. Bull WHO 53: 55-65. 
Wester KA, Benson GD, Gleason NM, Healy GR, Schultz MC 1970. Babesiosis in a Massachussetts resident. New Engl J Med 283: 854-856.

White DJ, Talarico J, Chaang HG, Birkhead GS, Heimberger T, Morse DL 1998. Human babesiosis in New York State: review of 139 hospitalized cases and analysis of prognostic factors. Arch Inter Med 158: 2149-2154.

Yoshinari NH, Barros PJL, Bonoldi VLN, Ishikawa M, Battestti DMB, Fonseca AHF, Schumaker TTS 1997. Perfil da borreliose de Lyme no Brasil. Rev Hosp Clin Fac Med São Paulo 52: 111-117.

Yoshinari NH, Barros PJL, Cruz FCM, Oyafuso LK, Mendonça M, Baggio D, Yasuda P, Cossermelli W.1992a. Clínica e sorologia da doença de Lyme no Brasil. Rev Bras Reumatol 32 (Supl.): 57.
Yoshinari NH, Barros PJL, Gauditano G, Fonseca AH, Bonoldi VLN, Costa IP, Barros-Battesti DM 2000. Report of 57 cases of Lyme-like disease (LLD) in Brazil. Arthritis Rheum 43 (Suppl.): S188.

Yoshinari NH, Barros PJL, Yasuda P, Baggio D, Steere AC, Cossermelli W1992b. Estudo epidemiológico da doença de Lyme no Brasil. Rev Hosp Clin Fac Med S Paulo 47: 240-244.

Yoshinari NH, Bonoldi VLN, Barros-Battestti D, Schumaker TS 1999. Doença de Lyme-símile no Brasil. Rev Bras Reumatol 39: 57-58.

Yoshinari NH, Oyafuso LK, Monteiro FGV, Barros PJL, Cruz FCM, Ferreira LGE, Bonasser F, Baggio D, Cossermelli W 1993. Doença de Lyme. Relato de um caso observado no Brasil. Rev Hosp Clin Fac Med São Paulo 48: 170-174. 